\title{
Pattern of Seasonal Water Use of Asian Pears Determined by Lysimeters and the Heat-pulse Technique
}

\author{
Horst W. Caspari ${ }^{1}$ \\ Institut für Obstbau und Gemüsebau, Universität Bonn, Auf dem Hügel 6,53121 Bonn, Federal Republic \\ of Germany
}

M. Hossein Behhoudian ${ }^{2}$ and David J. Chalmers ${ }^{3}$

Department of Plant Science, Massey University, Palmerston North, New Zealand

\author{
A. Richard Renquist ${ }^{4}$ \\ Orchard Mesa Research Center, Colorado State University, Grand Junction, CO 81503
}

Additional index words. Pyrus serotina, Nashi, Japanese pear, lysimetry, evapotranspiration, water use, heat-pulse technique

\begin{abstract}
Seasonal water use data are presented for 4-year-old Pyrus serotina Rehder cv. Hosui growing in drainage lysimeters and trained onto a Tatura trellis. Weekly water use (WU) was calculated using the mass balance approach. For 8 consecutive weeks during late summer, instantaneous WU was also measured by the compensation heat-pulse technique for measuring sap flow. Although good agreement was found between the two methods for 4 weeks after probe installation, discrepancies increased after this time. Water use was highest in early to mid-January in New Zealand, averaging $\approx 8$ liters/ tree per day, or 2 liters $\cdot m^{-2}$ canopy surface area/day. Total water use over the growing season was 1070 liters/tree, or 245 liters $\cdot \mathbf{m}^{-2}$ canopy surface area. The correlation coefficient between weekly WU and evaporation from a nearby Class A pan was 0.81 for the season. Weekly crop coefficients thus calculated for the well-watered trees ranged from 0.15 to 0.55 and 0.20 to 0.83 when calculated using canopy surface area and projected ground area, respectively. Low values were due to low values of canopy leaf area early in the season. Withholding irrigation during three periods resulted in a gradual decline in water use. Water-stressed trees had a lower predawn water potential than fully irrigated trees. This pattern was followed by a more-rapid decline during the morning, and a slower recovery during late afternoon and early evening. Midday leaf water potential never fell below -2.5 MPa.
\end{abstract}

Asian pears, known as Nashi in Australia and New Zealand, are a relatively new crop in the New Zealand fruit industry. The first experimental plantings were made in 1981, and commercial plantings started in 1984. Export volumes rose almost 6-fold from 51,000 trays (4 kg net weight of fruit/tray) in 1987 to 290,000 trays in 1990. Based on plantings in New Zealand up to 1986, an export crop potential approaching 1 million trays could be expected by 1992-93 (Drewitt, 1990). As these plantings reach maturity, information relating to proper irrigation management becomes increasingly important.

Crop coefficients $\left(\mathrm{k}_{\mathrm{c}}\right)$ are important in irrigation scheduling to match the evapotranspiration (ET) estimated from weather data, to crop ET. The former is often based on easy-to-use measurements of potential water use, such as the Class A pan. Irrigation volumes applied to replace water used by a crop will thus be too high if crop coefficients are overestimated.

Received for publication 12 Aug. 1992. Accepted for publication 9 Dec. 1992. Mention of trade names does not constitute a guarantee or warranty of the products by Massey Univ., nor does it imply endorsement of similar commercial products. We gratefully acknowledge the support of W.R.N. Edwards for the installation and maintenance of the heat-pulse equipment. H.W.C.'s research was supported by a grant from Gottlieb Daimler-und Karl Benz-Stiftung, Ladenburg, Federal Republic of Germany. A.R.R's research was funded by Colorado Agricultural Experiment Station project 138. The cost of publishing this paper was defrayed in part by the payment of page charges. Under postal regulations, this paper therefore must be hereby marked advertisement solely to indicate this fact.

'Visiting Scientist, to whom all correspondence should be addressed.

${ }^{2}$ Senior Lecturer.

${ }^{3}$ Professor. Current address: Cooperative Research Centre for Viticulture, P.O. Box 154, Glen Osmond, SA 5064, Australia.

${ }^{4}$ Visiting Scientist.
Consequences of over-irrigation include leaching of nutrients out of the root zone, increased drainage to water table, and reduced water-use efficiency. However, plants may experience water stress when water replacement is based on $\mathrm{k}_{\mathrm{c}}$ values that are too low. This stress can lead to suboptimal yields, depending on the degree and duration of stress, the susceptibility of the plant species to water stress, and the developmental stage of the plant.

A wide range of crop coefficients for a given species can be found in the literature. These differences are partly due to plant age, planting density, training system, and environment, but may also be affected by differences in the method used for relating actual ET to some measure of evaporation. For example, different estimates of the size of the evaporating plant canopy have been developed, such as planting square area, area covered or shaded by canopy, area actually wetted by emitters, trunk cross-sectional area, and canopy surface area (Elfving, 1982; Mitchell et al., 1991). Further, the term "crop coefficient" has been used to relate crop ET not only to reference evapotranspiration (ET,,), also known as potential ET, but also to unadjusted $\mathrm{E}_{\mathrm{pan}}$ values. Clearly, it would simplify comparison of data among sites or species, or both, if researchers agreed on a standard approach.

A drainage lysimeter was built at Massey Univ. in 1987 to study the water relations of Asian pears. Preliminary results obtained during the noncropping period indicated the drainage lysimeter was a reliable alternative to weighing lysimeters for monitoring ET of trees in a windy climate (Chalmers et al., 1992), when operated for $\approx 1$ week.

Abbreviations: DAFB, days after full bloom; DC, drying cycle; $\mathrm{E}_{\mathrm{pan}}$, potential water use measured from a Class A pan; ET, evapotranspiration; $\mathrm{k}_{\mathrm{c}}$, crop coefficient; WU, water use; $\Psi_{1}$, leaf water potential. 
The aims of the research presented here were to test further and improve the performance of the lysimeter installation; to determine the seasonal trend in crop water use for Asian pears in relation to the ambient weather conditions; and to obtain data on the effects of short-term water stress conditions on the water balance, tree water relations, and fruit growth and yield.

Extended periods of water deficit were not applied during the above experiments to avoid effects on tree growth and size that might confound the statistical design of later experiments.

\section{Materials and Methods}

Experimental conditions. The lysimeter facility of Massey Univ., Palmerston North, New Zealand (lat. $40.2^{\circ} \mathrm{S}$, long. $175.4^{\circ} \mathrm{E}$ ), is situated within a 1.1-ha block of Asian pears that was planted at the same time as the trees in the lysimeters in 1986-87. The whole block is within a bird canopy that reduces light levels by $15 \%$.

The facility consists of 12 drainage lysimeters, each a steel cylinder $1.2 \mathrm{~m}$ deep $\times 1 \mathrm{~m}$ in diameter. Each cylinder is surrounded by a concrete sleeve that gives a $1.2-\mathrm{m} /$ tree spacing within rows. The rows are $5 \mathrm{~m}$ apart and the ground cover is grass, with a 2-mwide herbicide-treated strip. The tops of the inner cylinders are $\approx 0.1 \mathrm{~m}$ above ground level.

The bottom $0.15 \mathrm{~m}$ of each steel container is filled with sand, while the bottom $0.05 \mathrm{~m}$ of the cylinder is conical in shape to provide drainage to a central discharge pond. A polyethylene pipe is connected to the outlet to transport drainage water. The resulting lysimeters allowed a total soil depth of $1 \mathrm{~m}$. Eight lysimeters were selected at random and carefully packed in $0.1-\mathrm{m}$ layers with Manawatu fine sandy loam excavated from the B horizon. To investigate the effect of soil layering on tree performance, the lower $0.4 \mathrm{~m}$ of the remaining lysimeters were similarly packed with the coarse, gravelly sand from the $\mathrm{C}$ horizon, with the B horizon above. This textural interface impedes unsaturated water transport, but water drains freely during saturated flow when the soil-water potential at the interface approaches zero. This arrangement mimics the natural layering and flow conditions of the surrounding orchard.

The Asian pear tree cultivar Hosui, grafted onto seedling rootstock, was planted in each of the lysimeters in Sept. 1987 and trained onto a Tatura trellis (Chalmers et al., 1978). Irrigation and fertilizer were applied to each tree via a closed nutrient-irrigation system fed from two 9100-liter tanks. Nutrient concentration of the solution was (in mg.liter ${ }^{-1}$ ) $105 \mathrm{~N}, 31 \mathrm{P}, 68.4 \mathrm{~K}, 125 \mathrm{Ca}, 48.6 \mathrm{Mg}$, 98 S, 3.0 Fe, 26.6 Cl, 0.5 B, 0.5 Mn, 0.05 Zn, 0.02 Cu, and 0.05 Mo. The $\mathrm{pH}$ of the solution was adjusted to 6.5 by adding sulfuric acid. The solution was pumped, filtered, and divided into three lines controlled by a solenoid, followed by a pressure regulator. Flow was metered using a Picoflux EV Superjet flow meter (Andrae Leonberg, Leonberg, Germany). Each solenoid was independently activated and supplied nutrient solution to a group of four lysimeters. Solution was applied to the surface of the soil in each lysimeter via eight pressure-compensated trickle emitters (Netafim, Israel). Each emitter was rated for 2 liters $\cdot h^{-1}$. Emitters were located in a circle some $0.3 \mathrm{~m}$ from the tree trunk to provide uniform water distribution. Individual lysimeters were covered with reflective, opaque plastic covers to minimize rainfall entry and soil evaporation.

The drainage from each lysimeter was routed through a polyethylene pipe to a tipping-bucket gauge (Pronamic, Them, Denmark) located within a subterranean control room. Automatic operation of the lysimeter facility was managed by a multitasking controller/datalogger (Wormald 1830, Christchurch, New Zealand).
Digital pulses from flow meters and drainage gauges were stored, and pump and solenoids controlled by the controller/datalogger. Irrigation and drainage volumes accumulated hourly were stored in arrays. Data from the arrays were automatically transferred to disk each day on an MS-DOS personal computer.

Additional details on design and performance of the lysimeter facility are given in Chalmers et al. (1992). Pesticides were applied according to standard cultural practice during maintenance of the surrounding orchard.

Soil moisture measurements. Access tubes for a neutron moisture meter were placed $0.2 \mathrm{~m}$ from the trunks of the trees in each lysimeter. A neutron hydroprobe (Model 503DR, CPN Corp., Martinez, Calif.) was used to take measurements twice weekly at 0.2-m depth intervals, from 0.2 to $1.0 \mathrm{~m}$ beneath the soil surface. Soil water storage (in $\mathrm{mm}$ ) was obtained by multiplying the volumetric Foil-water content $\left(\mathrm{m}^{3} \cdot \mathrm{m}^{-3}\right)$ by soil layer depth in $\mathrm{mm}$ $(300,200,200,200$, and 100 for the $0.2,0.4,0.6,0.8$, and $1.0 \mathrm{~m}$ measurement depths, respectively). This arrangement allowed conversion to liters of water storage per lysimeter by multiplying total soil-water storage by $0.785 \mathrm{~m}^{2} /$ lysimeter (since $1 \mathrm{~mm}=1$ liter $\cdot \mathrm{m}^{-2}$ ). "Pot capacity" was defined as the soil-moisture content when drainage from the lysimeters had ceased. There was no significant difference in pot capacity between the B- and B/Chorizon lysimeters.

Meteorological measurements. The $\mathrm{E}_{\mathrm{pan}}$ evaporation data were obtained from a Class A evaporation pan located $\approx 1 \mathrm{~km}$ from the lysimeter facility. Rainfall, sunshine hours, total daily wind run, and maximum and minimum temperatures were also recorded at that location.

Plant measurements. Water use (WU) was measured using an appropriate form of the conservation of water equation (Sharma, 1985): WU $=\mathrm{I}-\Delta \mathrm{W}-\mathrm{D}$, where $\mathrm{I}$ is irrigation, $\Delta \mathrm{W}$ is change in the soil-water storage, and D is drainage. Irrigation volumes for individual lysimeters were determined by dividing recorded flow meter volumes by four. The storage change $(\Delta \mathrm{W})$ was calculated from neutron probe readings, while $\mathrm{D}$ was that accumulated over the period.

Crop coefficients for Asian pears were determined by dividing mean weekly water use by weekly $\mathrm{E}_{\mathrm{pan}}$ data.

Between 18 Jan. and 13 Mar. 1991, transpiration of two neighboring trees in the lysimeters was also measured from the rate of sap movement upwards through the stem using the compensation heat-pulse technique (Swanson and Whitfield, 1981). Two thermistors, connected in a Wheatstone bridge configuration, were accurately placed $10 \mathrm{~mm}$ above and $5 \mathrm{~mm}$ below a 2-mm-diameter stainless steel heater. These heat-pulse probes were installed at depths of 5 and $15 \mathrm{~mm}$ below the cambium in both trees. The probe sets were placed at $\approx 20 \mathrm{~cm}$ above the graft union on the west side of the trees. Trunk diameters for the trees were 59.5 and $62.5 \mathrm{~mm}$, and canopy surface areas were 3.5 and $4.4 \mathrm{~m}^{2}$, respectively.

The interval between heat-pulse measurements was $20 \mathrm{~min}$, and the duration of the pulse was $1 \mathrm{sec}$. The heat-pulse data were recorded by a Custom Heat Pulse Logger (HortResearch, Palmerston North, New Zealand). Sap flux was derived from the corrected sap velocities according to Edwards and Warwick (1984). From 6 Feb. to 4 Mar., total sap flux for the larger tree was based on one probe only, due to malfunction of the second probe.

Leaf water potential $\left(\Psi_{1}\right)$ was measured once a week, using a Scholander pressure bomb (Soilmoisture Equipment Corp., Santa Barbara, Calif.), before sunrise (predawn $\Psi_{1}$ ) and at solar noon (midday $\Psi_{1}$ ) throughout the season. In addition, diurnal $\Psi_{1}$ measurements were made on several occasions.

The first flowers opened in mid-Sept. 1990, but full bloom, 
when $>95 \%$ of flowers had opened, was not until 7 Oct. The fruit were thinned 46 days after full bloom (DAFB) to $\approx 20 \mathrm{fruit} / \mathrm{m}^{2}$ canopy surface area. The change in fruit volume was calculated from weekly measurements of fruit diameter, using digital calipers, of at least 10 fruit/tree. Nashi fruit were assumed to be spherical. Measurements started 28 Nov. 1990 (i.e., 52 DAFB). A regression analysis between estimated fruit volumes and fruit volumes measured by water displacement indicated that using the above assumption, actual fruit volume was slightly overestimated $\left(\mathrm{Y}=0.15+0.92 \cdot \mathrm{X}, r^{2}=0.99, \mathrm{n}=97\right)$ using the maximum diameter, but slightly underestimated using the minimum diameter $(\mathrm{Y}=-1.8$ $\left.+1.09 \cdot \mathrm{X}, r^{2}=0.99, \mathrm{n}=52\right)$. The fruit density was $\approx 1.01 \mathrm{~g} \cdot \mathrm{cm}^{-3}$.

Growth of 67 shoots was measured weekly, starting 54 DAFB. Leaf stomata1 conductance $(\mathrm{g}$,) was measured on fully expanded, sunlit leaves with a transit-time porometer (Delta-T Devices, Model Mk3, Cambridge, United Kingdom).

Canopy surface area of each tree was calculated by summing the area of four inclined rectangles, two on either side of the Tatura trellis, which best represented the canopy outline in the plane of the trellis. Mean canopy surface area was $4.36 \mathrm{~m}^{2}$. Projected ground cover, (i.e., the area estimated to be covered by evaporating plant canopy) was $2.9 \mathrm{~m}^{2}$.

Irrigation regime. Between Oct. 1990 and Apr. 1991, trees were irrigated daily to keep the soil moisture at pot capacity, except for the periods 21 to 30 Dec. 1990 [75 to 84 DAFB, drying cycle 1 (DC-1)], 14 to 23 Jan. 1991 [99 to 108 DAFB, (DC-2)], and 28 Feb. to 13 Mar. 1991 [144 to 157 DAFB, (DC-3)]. During these periods, no irrigation was applied. At the end of DC-1, the lysimeters had dried down to an average of $\approx 60 \%$ of pot capacity when they were rewatered. Four trees were rewatered on 23 Jan., whereas the remaining trees were rewatered on the morning of 24 Jan., following a predawn $\Psi_{1}$ measurement. Three regimes of rewatering were applied during DC-3: four trees were returned to full irrigation on each of 11, 12, and 13 Mar., respectively, following the last $\Psi_{1}$ measurement for each day.

Data analysis. As in a previous study (Chalmers et al., 1992), no significant differences were observed between trees growing in B- or B/C-horizon lysimeters for any of the characteristics measured. The data presented here are the means of 12 trees, unless stated otherwise in the text.

\section{Results and Discussion}

Withholding irrigation resulted in a rapid decline in soil moisture in the lysimeters (Fig. 1). For the larger trees, the lysimeters could be dried down to $\approx 50 \%$ of pot capacity within 10 days. The decline was faster during DC-1 and DC-2 than DC-3, because of higher evaporative demands during those periods.

Mean daily $\mathrm{E}_{\mathrm{pan}}$ and $\mathrm{WU}$ varied considerably during the season (Fig. 2A). Substantial daily fluctuations in $\mathrm{E}_{\mathrm{pan}}$ with occasionally low daily $\mathrm{E}_{\mathrm{pan}}$ values, are typical of this region of New Zealand. Such variation is, however, masked when weekly averages are used (Fig. 2B). Mean daily water use increased steadily for the first 3 months following bloom and peaked at -8 liters/tree $(\approx 2$ liters $\cdot \mathrm{m}$ ${ }^{2}$ canopy surface area) in early-mid January $(\approx 90$ DAFB). This increase was due to the concurrent development of leaf area and evaporative demand. Leaf area was slightly reduced by summer pruning in early January (88 DAFB). 'Hosui' has three to four periods of intensive vegetative growth during one season. Generally, two or three growth flushes occur before the onset of rapid fruit growth, and one or two following harvest. Shoot growth slowed down (Fig. 3) by late December ( $\approx 80$ DAFB), and only shoots growing towards the inside of the $\mathrm{V}$-shaped canopy were

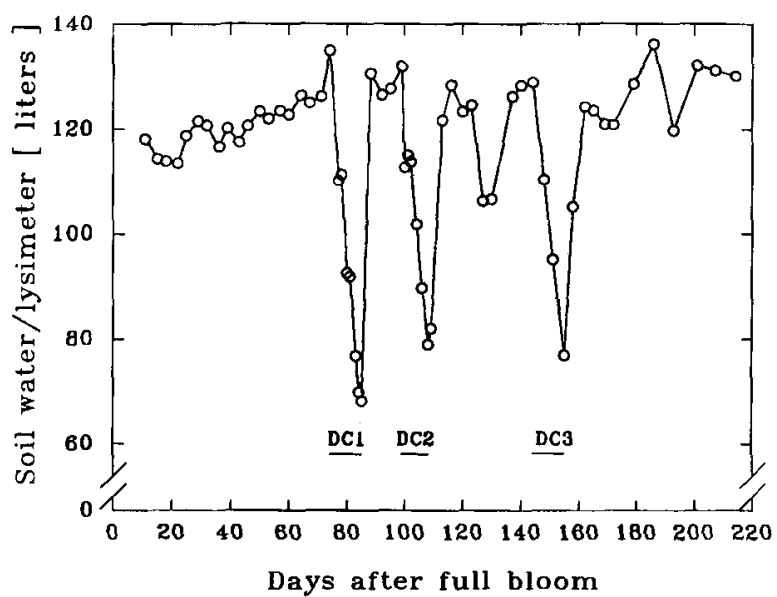

Fig. 1. Mean soil water content per lysimeter during the 1990-91 season. Horizontal lines represent drying cycles (DC).

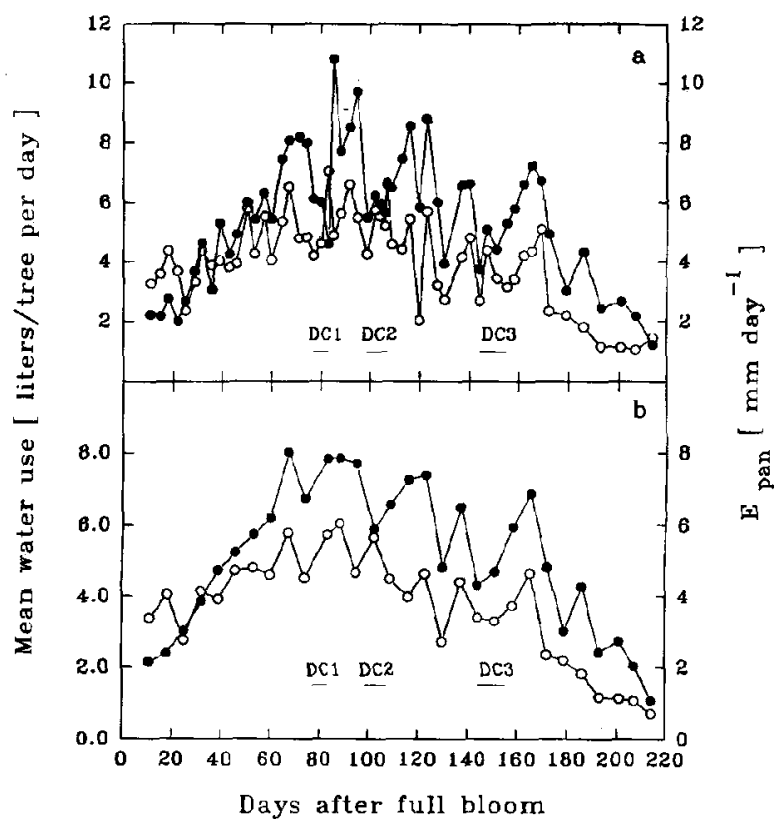

Fig. 2. Mean daily water use ( $)$ of 'Hosui' Asian pear trees growing in lysimeter and $\mathrm{E}_{\mathrm{pan}}$ values (O) for 18 Oct. 1990 to 9 May 1991 (11 to 214 days after full bloom) presented as (upper) 3-and 4-day averages and (lower) weekly averages. Horizontal lines represent drying cycles (DC).

removed by summer pruning.

During periods when soil moisture was not limiting, daily WU averaged $\approx 7.0$ liters/tree (1.8 liters $\cdot \mathrm{m}^{-2}$ canopy surface area) from mid-January to harvest (109 to $130 \mathrm{DAFB}$ ), and $\approx 4.5$ liters/tree (1.1 liters $\cdot \mathrm{m}^{-2}$ canopy surface area) following harvest until the first signs of leaf senescence in mid-April (186 DAFB) (Fig. 2B). Similar values were found for noncropping Asian pears in late Summerand Autumn 1990 (Chalmers et al., 1992). Seasonal water use (Oct. 1990 to May 1991) averaged 1070 liters/tree (245 liters $\cdot \mathrm{m}^{-2}$ canopy surface area), and $\mathrm{E}_{\mathrm{pan}}$ was $780 \mathrm{~mm}$.

There was a good linear correlation between weekly $\mathrm{E}$ and water use over the season $(r=0.81, \mathrm{n}=30)$. This correlation was lower $(r=0.69)$ when 3 - and 4-day averages were used. Similarly, Worthington et al. (1984) reported a daily correlation coefficient of 0.61 for peaches [Prunus persica (L.) Batsch] growing in weighing lysimeters. The correlation was improved $(r=0.88, \mathrm{n}=$ 18) when weekly averages were used. They also concluded that 
whereas estimation of evapotranspiration of peaches using the Class A pan is suitable over longer periods, it may not be as meaningful on a daily basis.

Crop coefficients were derived from weekly $\mathrm{E}_{\mathrm{pan}}$ and water-use data, so that $\mathrm{k}_{\mathrm{c}}=\mathrm{WU} / \mathrm{E}_{\mathrm{pan}}$. When calculated on the basis of the canopy surface area or the projected ground area of the trees, these coefficients ranged from 0.15 to 0.55 and 0.20 to 0.83 , respectively. Their averages for the season were 0.34 and 0.51 , respectively. Similar values were obtained for the 1991-92 season (unpublished data). The crop coefficients increased with time through the season, but with increasing variability close to leaf fall. Withholding irrigation reduced crop coefficients (Fig. 4). During summer and autumn, Chalmers et al. (1992) found weekly $\mathrm{k}_{\mathrm{c}}$ values for well-watered Asian pears averaged 0.52 (canopy surface area basis), but these declined to 0.38 when irrigation was withheld.

Water use declined when irrigation was withheld (Fig. 5). In these experiments the decline was more pronounced for the first two drying cycles due to higher evaporative demands and, possibly, the effect of fruit load. The presence of fruit has been shown to increase transpiration or stomatal conductance, or both, in peaches [Prunus persica (L.) Batsch] (Chalmers et al., 1983), grapes (Vitis vinifera L.) (Downton et al., 1987), and apples (Malus domestica Borkh.) (Hansen, 1971; Lenz, 1986). Transpiration of peach trees was higher in fruiting than in defruited trees during rapid fruit growth (DW III), but decreased when fruit were removed at harvest (Chalmers et al., 1983).

At the start of the drying cycles, trees transpired at a rate similar to trees under full irrigation (Fig. 5). With decreasing soil moisture levels, water use gradually declined. Correlation coefficients between WU and $\mathrm{E}_{\mathrm{pan}}$ for the drying cycles were low (0.16), showing the diminishing effect of weather on water use as the available soil moisture decreased.

Heat-pulse data during DC-2 not only confirmed this gradual decline in WU, but also showed differences in the degree to which the water use declined. Trees with a larger canopy surface area depleted the available soil water faster at the start of a drying cycle than smaller trees. Toward the end of the drying cycle, the larger trees were more severely stressed than smaller trees, which resulted in a substantial reduction in daily water use. At the beginning of DC-2 [ 14-23 Jan. for large trees; 14-22 Jan. for small trees (Fig. 6)], the larger tree transpired at a rate $35 \%$ higher than the smaller tree. Soil moisture for the large and small tree then fell to $58 \%$ and $71 \%$ of pot capacity, respectively. Close to the end of DC2 , under conditions of decreased water availability, both trees used a similar amount of water on an instantaneous basis. Irrigating one tree while continuing to withhold water from the other resulted in a higher instantaneous water use by the irrigated tree (Fig. 6). Because of differences in tree size (i.e., trunk cross-sectional areas), the effect of rewatering is more obvious when sap velocities instead of total sap fluxes are compared. Sap velocities in both stems dropped during the drying cycle. As a result of irrigation, the sap velocity in the irrigated tree increased, while the sap velocity in the nonirrigated tree continued to decline (Fig. 7).

Stomatal conductance decreased in both trees compared to well-watered conditions, yet were two to three times higher in the rewatered tree than the nonirrigated one (A.R. Renquist, unpublished data). After both trees were returned to full irrigation, it took 4 to 5 days for the initial ratio of water use between the two trees to be re-established (Fig. 8).

Water-stressed trees had a lower predawn leaf water potential $\left(\Psi_{1}\right)$ than fully irrigated trees, and $\Psi_{1}$ followed a more rapid decline during the morning, and a slower recovery during late afternoon

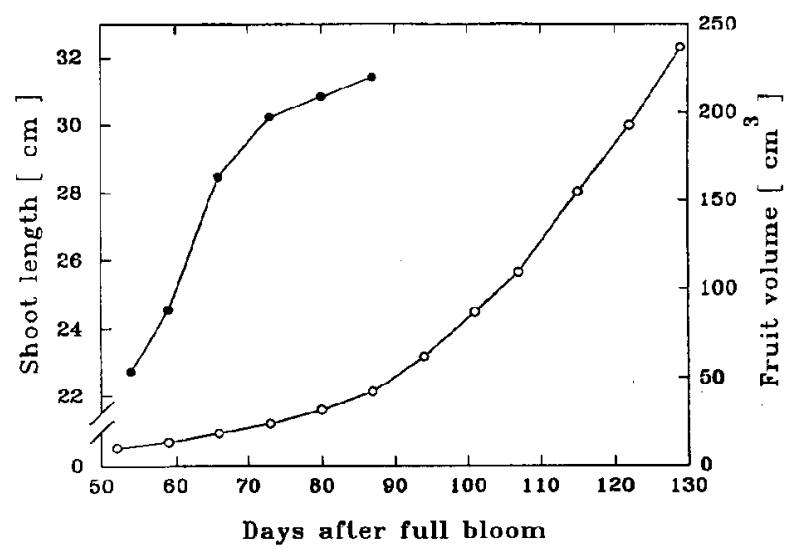

Fig. 3. Shoot (O) and fruit (O) growth of 'Husui' Asian pear trees growing in lysimeter during 1990-91 season. Only one shoot growth flush is shown.

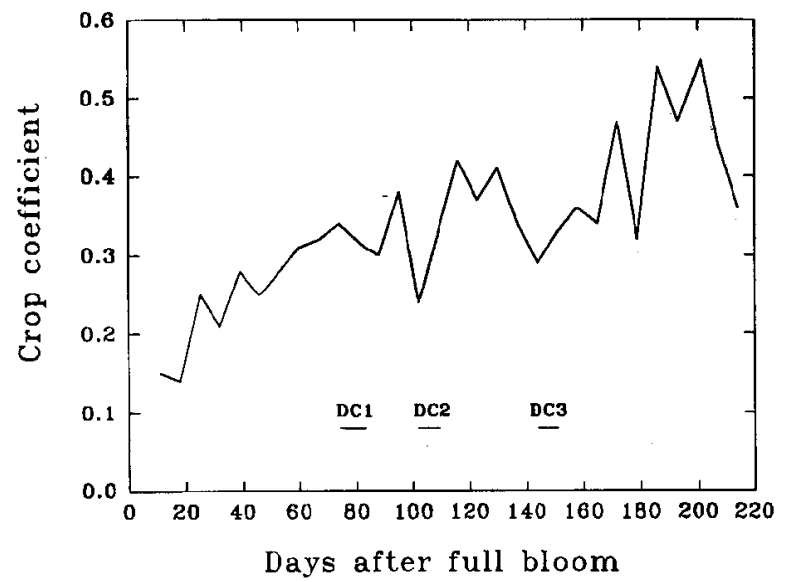

Fig. 4. Seasonal change of crop coefficient (water use/ $\mathrm{m}^{2}$ canopy surface area per $E_{\text {pan }}$ ) of 'Hosui' Asian pears. Horizontal lines represent drying cycles (DC).

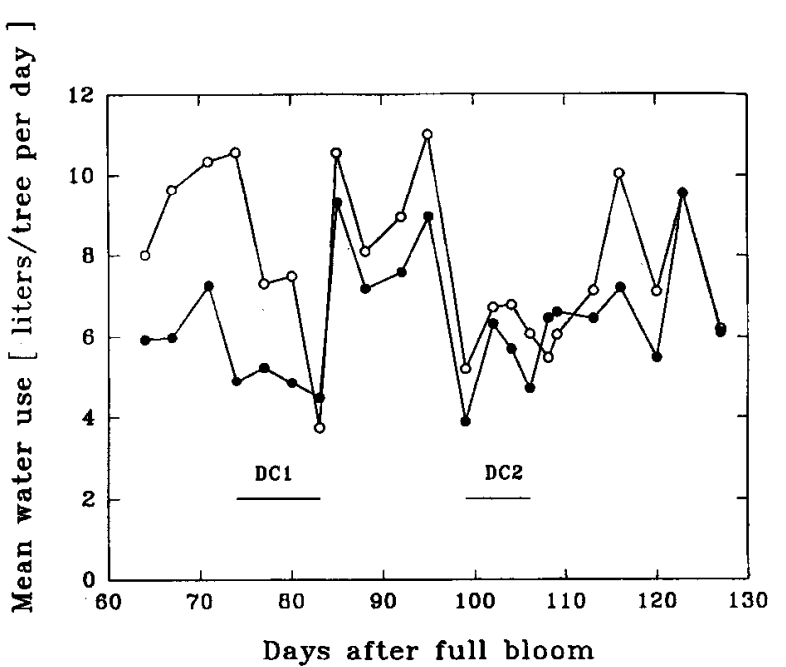

Fig. 5. Mean daily water use of a 'Hosui' Asian pear tree with $4.4 \mathrm{~m}^{2}$ canopy surface area $(O)$ and one with $3.5 \mathrm{~m}^{2}$ canopy surface area $(O)$ before, during, and following drying cycles (DC) 1 and 2 . Horizontal lines represent DC.

(Fig. 9). Predawn $\Psi_{1}$ dropped during the drying cycles, yet returned to prestress values once irrigation was restored (Table 1). The midday $\Psi_{1}$ of stressed trees never fell below $-2.5 \mathrm{MPa}$, although well-watered trees also had leaf water potentials of this value at midday on days when evaporative demand was high. Accordingly, predawn and late afternoon proved to be better than the midday to discriminate between water-stressed and irrigated trees using leaf 


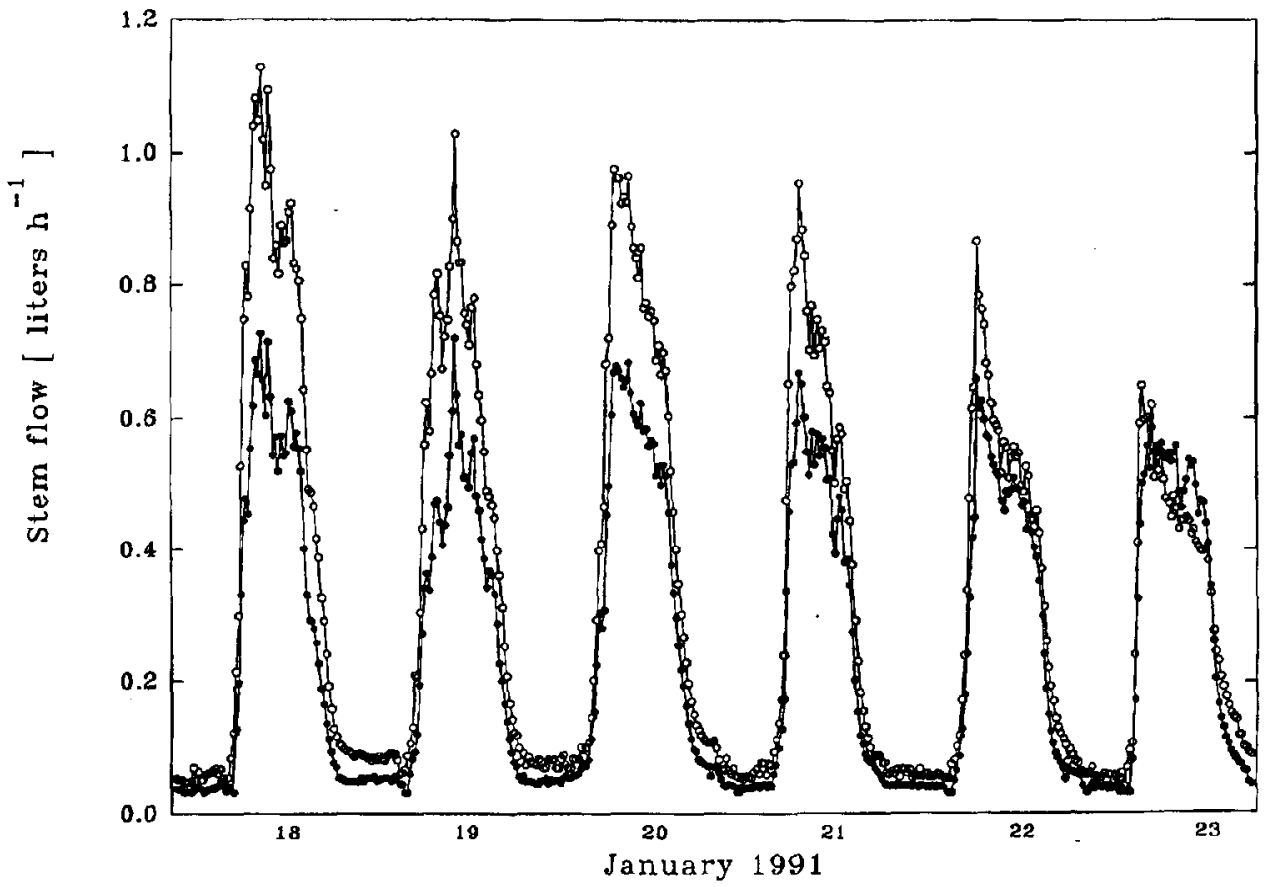

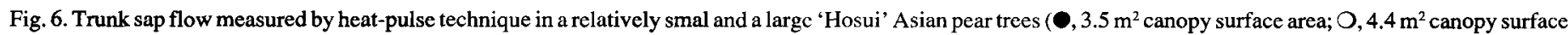
area) for day 5 to day 10 of a 10-day drying cycle. Irrigation for the larger tree was withheld from 14 to 23 Jan. 1991 [99 to 108 days after full bloom (DAFB)], and for the smaller tree from 14 to 22 Jan. 1991 ( 99 to 107 DAFB).

water potential measurements. In contrast, Behboudian (unpublished data), in a greenhouse study on 'Nijisseiki' Asian pears, found differences in midday $\Psi_{1}$ between well-watered and waterstressed trees to be more pronounced than predawn values. In our experiment, differences in $\Psi_{1}$ between rewatered and dry treatments became significant (Fig. 10 and Fig. 11) during the late afternoon. Leaf water potentials of trees rewatered on 23 Jan. 1991 (108 DAFB) were not significantly different to $\Psi_{1}$ of nonirrigated trees for most of the day (Fig. 10), but showed a faster recovery during late afternoon. In addition, rewatered trees had a significantly higher predawn $\Psi_{1}$ on the morning of 24 Jan. 1991 (data not shown). Similarly, during DC-3, significant differences were observed for the last measurements on 12 and 13 Mar. 1991 (156 and 157 DAFB) (Fig. 11). After all trees were returned to full irrigation, predawn $\Psi_{1}$ on 14 Mar. 1991 (158 DAFB) was similar for all treatments (Fig. 11). For 14 Mar. 1991 completion of diurnal measurements was prevented by rainfall.

Although a strong reduction in WU was observed in DC-1, there was no effect on the rate of fruit growth (Fig. 3). In contrast, during DC-2, the strong reduction in WU appeared to inhibit fruit growth. Without a well-irrigated control for comparison, however, no conclusion can be drawn about how the water deficits affected fruit growth during the two drying cycles. Mild water stress during early or late stages of fruit growth had no deleterious effects on fruit growth of 'Nijisseiki' Asian pears (Behboudian, unpublished data) and apples (Durand, 1990; Irving and Drost, 1987). Thus, it appears that fruit were more efficient sinks for reduced photosynthates and water than leaves. which could account for the capacity

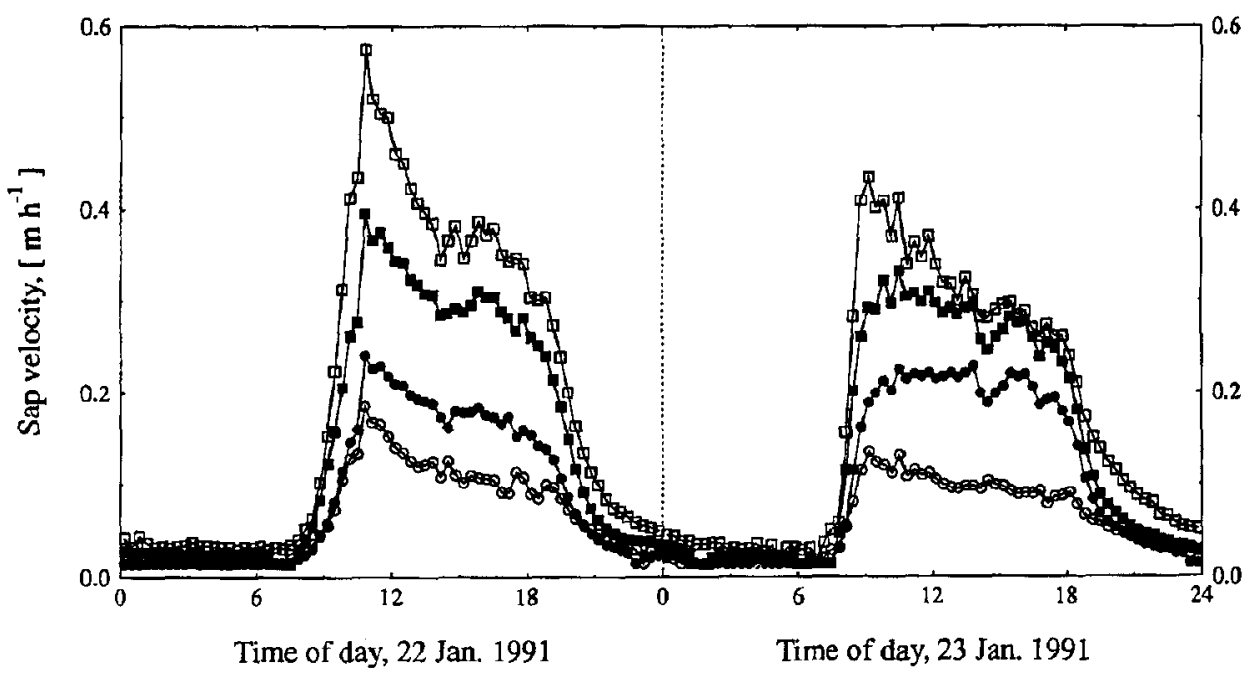

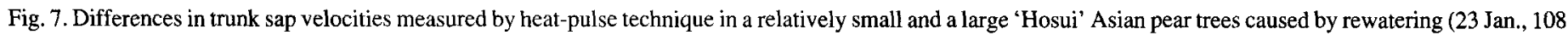
days after full bloom). Filled symbols represent rewatered tree $\left(3.5 \mathrm{~m}^{2}\right.$ canopy surface area), open symbols represent nonirrigated tree (4.4 $\mathrm{m}^{2}$ canopy surface area). Circles and squares represent sensors at depths of $5 \mathrm{~mm}$ and $15 \mathrm{~mm}$ below cambium, respectively. 


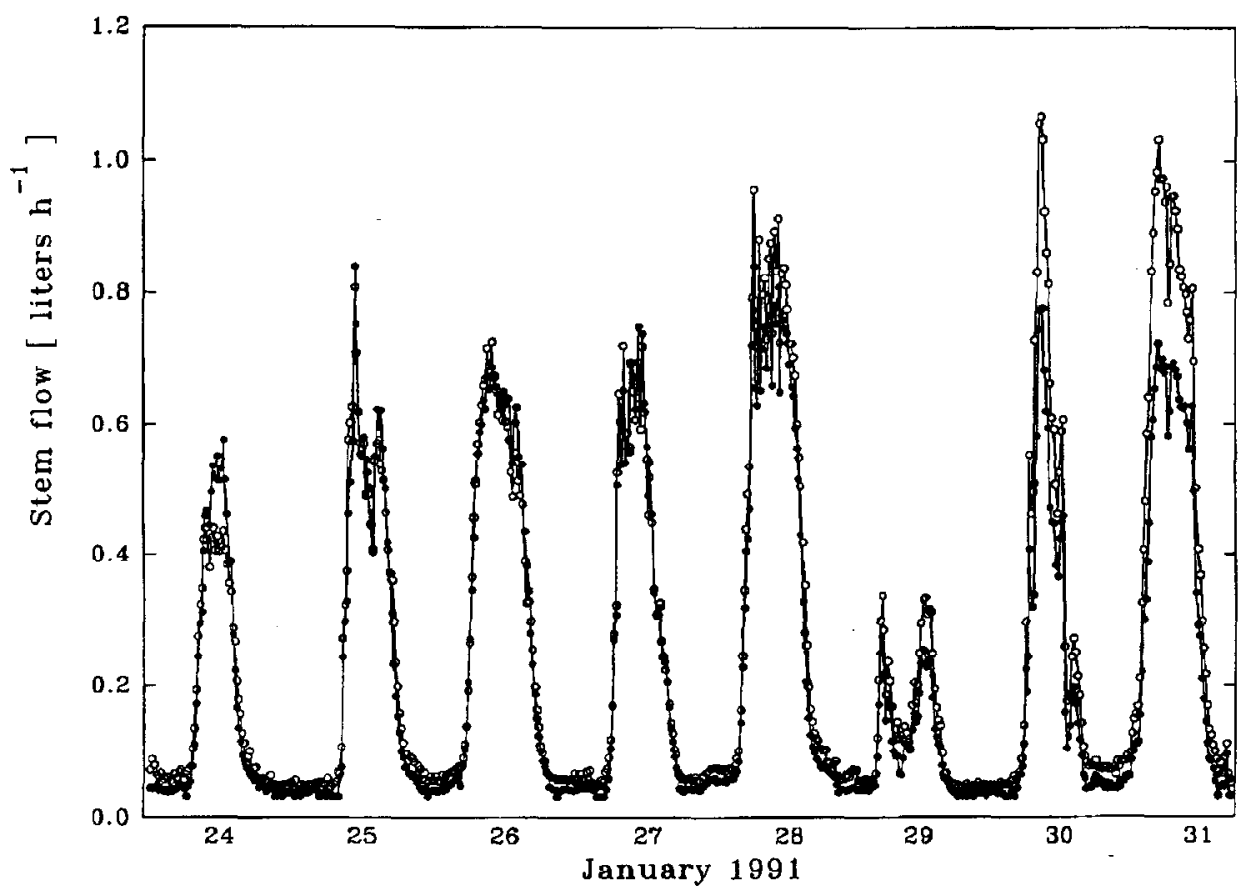

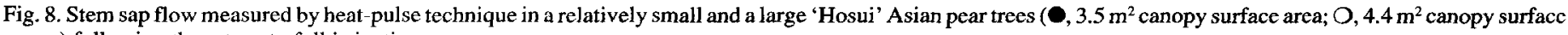
area) following the return to full irrigation.

of fruit to grow at low water potentials (Chalmers et al., 1986). This hypothesis is supported by Behboudian (unpublished data), who found that fruit had higher water potentials than leaves before dawn and at midday, and that osmotic adjustment occurred in fruit of the early stress treatment, but not in fruit when trees were deficitirrigated close to harvest.

For the entire period, the heat-pulse data indicated a $0.5 \%$ higher and $17 \%$ lower total WU than the lysimeter for the bigger and smaller tree, respectively (Table 2). There was a good agreement between the two methods in measuring WU for the first 4 weeks, but WU values based on the heat-pulse technique became more variable after this initial period. Consequently, the regression coefficients between heat-pulse and lysimetry declined from 0.97 and 0.95 for the first 4 weeks to 0.87 and 0.83 for the smaller and bigger tree, respectively, over the entire period. These results are consistent with other work, which has found sensors became between $2 \%$ and $25 \%$ less sensitive after 30 days (Swanson, 1983).

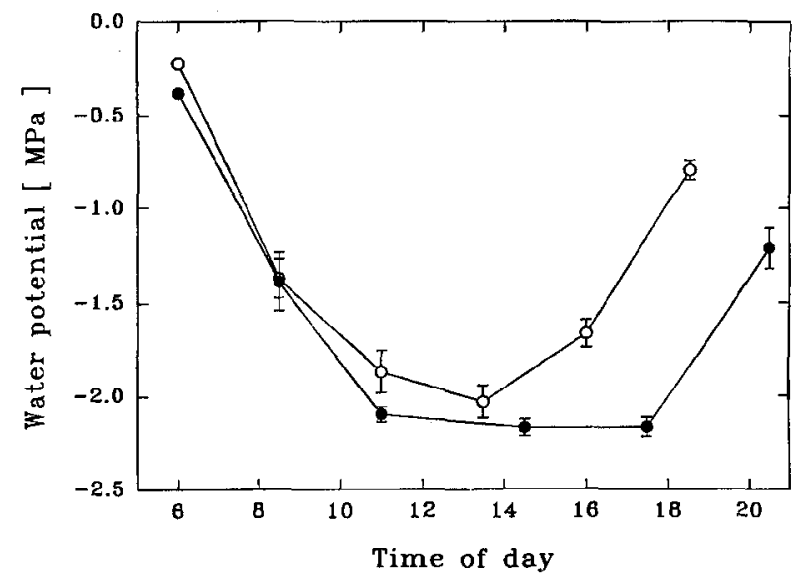

Fig. 9. Diurnal changes in leaf water potential of well-watered $(O)$ and waterstressed (O) 'Hosui' Asian pear trees. Bars represent twice SE.
The degree to which sensors lost sensitivity was seasonal. Sensors installed in August (northern hemisphere) registered $\approx 98 \%$ of actual stem flow after being installed for 50 days, whereas sensors installed in May recorded just $70 \%$. It appeared that the wound response of the tree was related to the phenological period during which the wounding occurred (Swanson, 1983).

The crop coefficients for Asian pears reported here and by Chalmers et al. (1992) are lower than $\mathrm{k}_{\mathrm{c}}$ values of 0.4 to 1.0 (Worthington et al., 1984) and 0.69 to 1.25 (Natali et al., 1985), on a projected ground area basis, for peaches, or 0.95 to 1.0 and 1.05 to 1.1 for European pears (Pyrus communis L.) and apples, respectively (Doorenbos and Pruitt, 1977). Since individual pots of the lysimeter were covered and evaporation from the soil surface is directly related to net radiation, it can be assumed that this contribution to total WU was minimal, particularly under the humid conditions in New Zealand (Jensen et al., 1989). Contribution of evaporation from the surface of the soil to total WU is

Table 1. Predawn leaf water potentials ( $\left.\Psi_{1}\right)$ of 'Hosui' Asian pears before, during, and following drying cycles (DC; Nov. 1990 to Mar. 1991, 36 to 158 days after full bloom).

\begin{tabular}{lcc}
\hline \hline $\begin{array}{l}\text { Observation } \\
\text { period }\end{array}$ & $\begin{array}{c}\text { Days of } \\
\text { test }\end{array}$ & $\begin{array}{c}\text { Predawn } \Psi_{1} \\
\text { (MPa) }\end{array}$ \\
\hline $\begin{array}{l}\text { Prestressed } \\
\text { DC-1 }\end{array}$ & 9 & -0.19 to -0.27 \\
Well-watered & 11 & -0.33 \\
$\quad$ DC-2 & & -0.58 \\
& 10 & -0.20 to -0.22 \\
Well-watered & 11 & -0.39 \\
$\quad$ DC-3 & 12 & -0.45 \\
& 13 & -0.14 to -0.25 \\
& 14 & -0.26 \\
Well-watered & & -0.31 \\
& & -0.32 \\
\end{tabular}


largest early in the growing season, and at low planting densities (Loreti et al., 1988). Stevenson (1989), comparing total water use of 'Macspur McIntosh' apple trees growing in lysimeter with and without a grass cover crop, found WU to be lower in the bare soil treatment. The differences were small, averaging $8 \%$ for nine growing seasons. Low evaporation from the soil surface, however, could only partly explain the substantially lower $\mathrm{k}_{\mathrm{c}}$ found in this study. Similar values found for the 1991-92 season (unpublished data) suggest a lower crop coefficient for Asian pears than for European pears and apples.

The lysimeter facility described here proved to be a valuable system for studying water relations of Asian pears. The system enabled a good control of the soil water level, and thereby good control of the plant water status, and accurate measurement of water use. These results confirm observations by Chalmers et al. (1992) that Asian pears grown on a Tatura trellis have a rather low maximum water use under the humid New Zealand climate. Predawn and late-afternoon leaf water potentials were good indicators of the plant water status, whereas midday leaf water potential was more strongly influenced by climatic conditions. Since the main portion of vegetative growth of 'Hosui' occurred before the

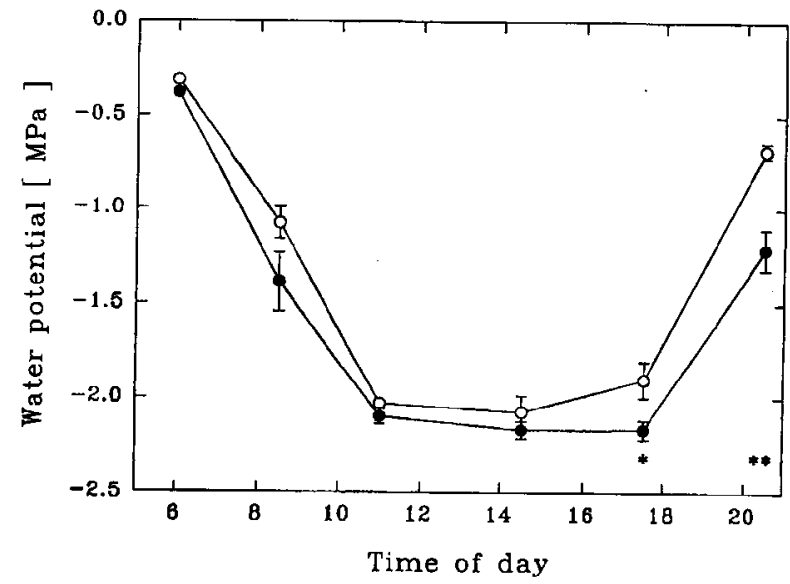

Fig. 10. Diumal changes (23 Jan. 1991) in leaf water potential for dry (O) and rewatered $(O)$ 'Hosui' Asian pear trees. Bars represent twice SE. Mean separation by Duncan's multiple range test. *** Significant at $P=0.05$ or 0.01 , respectively.

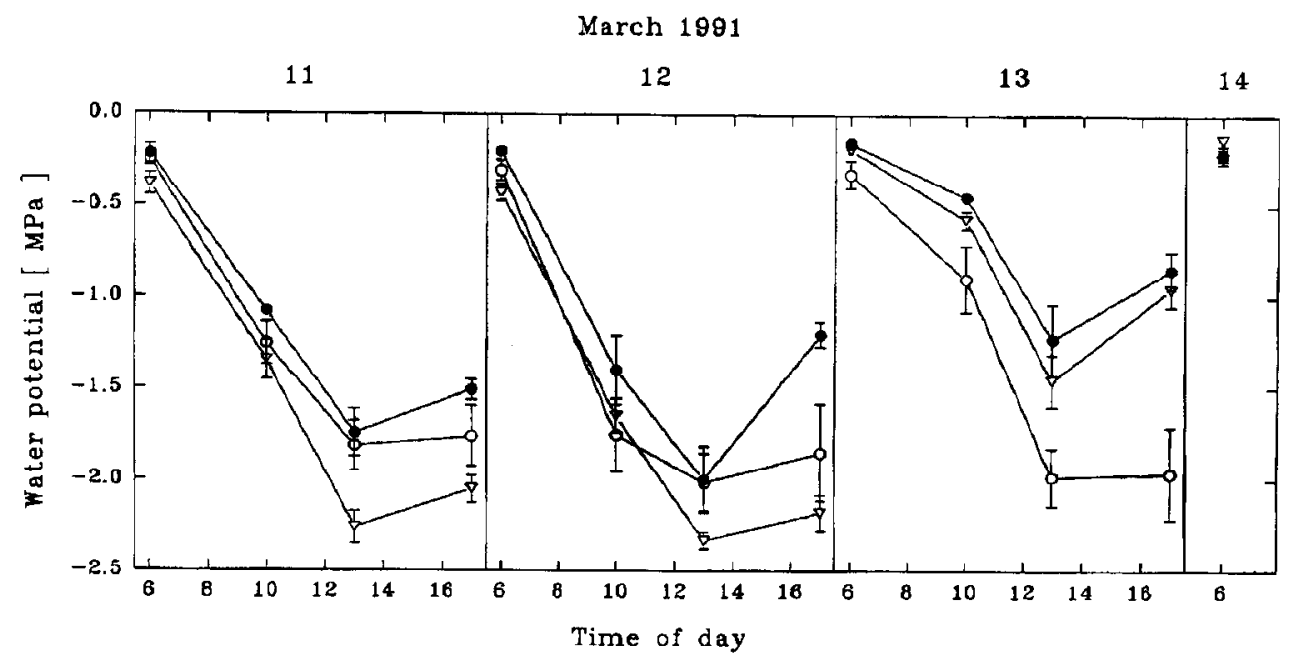

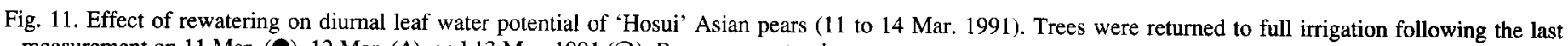
measurement on 11 Mar. (O), 12 Mar. ( $\Delta$ ), and 13 Mar. $1991(\bigcirc)$. Bars represent twice sE.

Table 2. Comparison of water use [liters/tree] of 'Hosui' Asian pear trees, calculated from lysimetry and heat-pulse measurements.

\begin{tabular}{|c|c|c|c|c|c|}
\hline \multirow{3}{*}{$\begin{array}{l}\text { Observation } \\
\text { period }\end{array}$} & \multirow{3}{*}{$\begin{array}{l}\text { Days after } \\
\text { full bloom }\end{array}$} & \multicolumn{4}{|c|}{ Tree size (relative) } \\
\hline & & \multicolumn{2}{|c|}{ Small } & \multicolumn{2}{|c|}{ Large } \\
\hline & & Heat-pulse & Lysimetry & Heat-pulse & Lysimetry \\
\hline 17-20 Jan. ${ }^{\mathrm{z}}$ & 102 to 105 & 18.8 & 24.0 & 28.2 & 27.0 \\
\hline 21-23 Jan. & 106 to 108 & 17.4 & 17.9 & 20.9 & 17.6 \\
\hline 24-27 Jan. & 109 to 112 & 22.0 & 26.4 & 22.6 & 24.2 \\
\hline 28-30 Jan. & 113 to 115 & 14.9 & 19.4 & 18.4 & 21.4 \\
\hline 31 Jan. to $3 \mathrm{Feb}$. & 116 to 119 & 25.8 & 28.8 & 36.1 & 40.2 \\
\hline 4-6 Feb. & 120 to 122 & 13.8 & 16.5 & 19.7 & 21.3 \\
\hline 7-10 Feb. & 123 to 126 & 29.5 & 38.2 & 39.2 & 38.2 \\
\hline 11-13 Feb. & 127 to 129 & 15.6 & 18.3 & 21.7 & 18.6 \\
\hline 21-24 Feb. & 137 to 140 & 21.2 & 26.1 & 29.4 & 28.0 \\
\hline 25-27 Feb. & 141 to 143 & 15.1 & 21.7 & 22.8 & 22.7 \\
\hline 28 Feb.-3 Mar. & 144 to 147 & 15.6 & 13.5 & 24.7 & 13.4 \\
\hline 7-10 Mar. & 151 to 154 & 17.9 & 16.9 & 19.6 & 24.2 \\
\hline 11-13 Mar. & 155 to 157 & 12.6 & 21.2 & 12.7 & 17.7 \\
\hline
\end{tabular}

${ }^{\mathrm{z}}$ Heat-pulse values for 18-20 Jan. 1991. 
start of rapid fruit enlargement, when about two-thirds of final fruit weight was accumulated, Asian pears may also respond favorably to regulated deficit irrigation (RDI) (Chalmers et al., 1986).

\section{Literature Cited}

Chalmers, D.J., P.K. Andrews, K.M. Harris, E.A. Cameron, and H.W. Caspari. 1992. Performance of drainage lysimeters for the evaluation of water use by Asian pears. HortScience 27:263-265.

Chalmers, D.J., G. Burge, P.H. Jerie, and P.D. Mitchell. 1986. The mechanism of regulation of 'Bartlett' pear fruit and vegetative growth by irrigation withholding and regulated deficit irrigation. J. Amer. Soc. Hort. Sci. 111:904-907.

Chalmers, D.J., K.A. Olsson, and T.R. Jones. 1983. Water relations of peach trees and orchards, p. 197-232. In: T.T. Kozlowski (ed.). Water deficit and plant growth, vol. 7. Academic Press, New York.

Chalmers, D.J., B. van den Ende, and L. van Heek. 1978. Productivity and mechanization of the Tatura trellis orchard. HortScience 13:517-521.

Doorenbos, J. and W.O. Pruitt. 1977. Guidelines for predicting crop water requirements. Food and Agricultural Organization (FAO) Irrigation and Drainage Paper 24. FAO, United Nations, Rome.

Downton, W.J.S., W.J.R. Grant, and B.R. Loveys. 1987. Diurnal changes in the photosynthesis of field-grown grape vines. New Phytol. 105:7180 .

Drewitt, B. 1990. The international marketplace, p. 78-82. In: A.G. White (ed.). Nashi-Asian pear in New Zealand. DSIR Publishing, Wellington, New Zealand.

Durand, G., 1990. Effects of RDI on apple tree (cv. Royal Gala) growth, yield and fruit quality in humid environment. PhD Thesis, Massey Univ., Palmerston North, New Zealand.

Edwards, W.R.N. and N.W.M. Warwick. 1984. Transpiration from a kiwifruit vine as estimated by the heat pulse technique and the PenmanMonteith equation. N.Z. J. Agr. Res. 27:537-543.
Elfving, D.C. 1982. Crop response to trickle irrigation. Hort. Rev. 4:1-48. Hansen, P. 1971. The effect of fruiting upon transpiration rate and stomata1 opening in apple leaves. Physiol. Plant. 25:181-183.

Irving, D.E. and J.H. Drost. 1987. Effects of water deficit on vegetative growth, fruit growth and fruit quality in Cox's Orange Pippin apple. J. Hort. Sci. 62:427-432.

Jensen, M.E., R.D. Burman, and R.G. Allen (eds.). 1989. Evapotranspiration and irrigation water requirements. Amer. Soc. Civil Eng., New York.

Lenz, F. 1986. Fruit effects on transpiration and dry matter production in apples, p. 101-104. In: A. Lakso and F. Lenz (eds.). The regulation of photosynthesis in fruit trees. Symp. Proc. Publ. N.Y. State Agr. Expt. Sta., Geneva.

Loreti, F., R. Massai, and S. Natali. 1988. Ricerche sul fabbisogno idrico de1 pesco in relazione ai portinnesti, alle forme di allevamento e alle densita di piantagione, p. 169-181. Proc. XVIII Convegno Peschicolo, Cesena.

Mitchell, P.D., A.M. Boland, J.L. Irvine, and P.H. Jerie. 1991. Growthand water use of young, closely planted peach trees. Scientia Hort. 47:283293.

Natali, S., C. Xiloyannis, and M. Mugano. 1985. Water consumption in high density peach trees. Acta Hort. 173:413-420.

Sharma, M.L. 1985. Estimating evapotranspiration. Adv. Irr. 3:213-281.

Stevenson, D.S. 1989. Irrigation subsurface return flows and water use in lysimeters containing apple trees. Can. J. Soil Sci. 69:769-778.

Swanson, R.H. 1983. Numerical and experimental analyses of implantedprobe heat pulse velocity theory. PhD Thesis, Univ. of Alberta, Edmonton, Canada.

Swanson, R.H. and D.W.A. Whitfield. 1981. A numerical analysis of heat pulse velocity theory and practice. J. Expt. Bot. 32:221-239.

Worthington, J.W., M.J. McFarland, and P. Rodrigue. 1984. Water requirements of peach as recorded by weighing lysimeters. HortScience 19:90-91. 